\title{
Effects of simultaneous treatment with PMX-DHP and sivelestat on endotoxaemia in conscious guinea pigs
}

\author{
Saori Ishinokami ${ }^{1}$, Kayo Nemoto ${ }^{1,3}$, Norifumi Ninomiya ${ }^{1}$, Masamune Kuno ${ }^{1}$ \\ Minoru Kubota $^{2}$, Kensuke Suzuki ${ }^{1}$, Hiroyuki Yokota ${ }^{1}$
}

\begin{abstract}
Using an endotoxaemia model in conscious guinea pigs, we previously reported that polymyxin B immobilized fiber-direct hemoperfusion (PMX-DHP) or administration of sivelestat are effective treatments for sepsis. In the present study, we investigated whether simultaneous treatment with PMX-DHP and sivelestat sodium was more effective than either treatment alone for sepsis. Measurements examined included intestinal paralysis, blood pressure, serum HMGB1 level and survival rate. Colonic motion was monitored continuously by telemetry using a transducer attached to the taenia caecum, while blood pressure was monitored with a carotid artery catheter. The guinea pigs were divided into 4 groups and lipopolysaccharide (LPS) was administered to all animals. The control group received only LPS. The remaining three groups received PMX treatment for 2 hours, sivelestat sodium administration for 2 hours or simultaneous PMX and sivelestat treatment for 2 hours. In the control group, decreased colonic muscle tension and arterial pressure, and increased serum HMGB1 levels were observed and all animals died within 30 hours. In the PMX-DHP treated group, the decreases in colonic tension and arterial pressure were less severe than for the control group and the survival rate was higher than the control group, but serum HMGB1 levels were not significantly different. In the sivelestat group, decreases in colonic tension and arterial pressure were not significantly different with the control group, but serum HMGB1 levels were lower than in the control group. Simultaneous treatment with both PMX-DHP and sivelestat sodium did not exhibit synergistic effects for the treatment of LPS- induced endotoxaemia and mortality. PMX-DHP was effective at treating sepsis induced by administration of a high dose of LPS in guinea pigs, but simultaneous administration of sivelestat sodium did not augment the efficacy of PMX-DHP treatment.
\end{abstract}

(JJAAM. 2012; 23: 12-20)

Keywords: HMGB-1, intestinal paralysis, lipopolysaccharide, sepsis

\section{INTRODUCTION}

LPS simultaneously activates multiple, parallel cascades that contribute to the pathophysiology of adult respiratory distress syndrome (ARDS) and septic shock. The effect of LPS precedes monocyte, neutrophil and

\footnotetext{
${ }^{1}$ Department of Emergency and Critical Care Medicine, Nippon Medical School, Tokyo, Japan

${ }^{2}$ Department of Clinical Laboratory, Tama Nagayama Hospital, Nippon Medical School, Tokyo, Japan

${ }^{3}$ Shinjuku Vocational College of Acupuncture and Judo Therapy, Tokyo, Japan

Correspondence to: Dr. Saori Ishinokami, Department of Emergency and Critical Care Medicine, Tama Nagayama Hospital, Nippon Medical School, 1-7-1 Nagayama, Tama-shi, Tokyo 206-8512, Japan
}

platelet activation. Therefore, LPS-induced effects are reported to occur multiple biochemical effects ${ }^{1)}$. Monocytes release cytokines that activate neutrophils, lymphocytes and the vascular endothelium and up-regulate cellular adhesion molecules. Neutrophils release elastases and superoxide- derived free radicals that directly damage tissues. Platelets release 2-arachidonoil glycerol (2$\mathrm{AG})$, an endogenous cannabinoid, that regulates intestinal and vascular tones ${ }^{2,3}$.

Ninomiya $\mathrm{N}$, et $\mathrm{al}^{4}$. have reported that LPS administration induces the production of 2-AG, leading to paralytic ileus mediated by cannabinoid (CB)-1 receptors. It has been shown that the elimination of 2-AG by polymyxin $\mathrm{B}$ immobilized fiber-direct hemoperfusion (PMX-DHP) reduces paralytic ileus ${ }^{5)}$. In cases of patients with increased blood pressure resulting from PMX-DHP treatment, the plasma concentration of 2-AG was decreased ${ }^{6,7)}$.

Neutrophil elastase (NE) is a liposomal protease that is 
released in response to inflammation. NE exhibits proteolytic activity on connective tissues, coagulated blood, fibrinolytic factors and complement factors. The proteolytic activities of NE result in ARDS- related lung injury. Sivelestat sodium hydrate (sivelestat) is a specific NE inhibitor that inhibits increases in vascular permeability mediated by NE. Sivelestat is used to treat acute lung injury (ALI ${ }^{8,9)}$. In Japan, sivelestat has been widely used in clinical practice since 2002. However, in the United States and Europe, the effectiveness of sivelestat was not observed in the multi-center, double-blind, placebo-controlled trial (STRIVE study) ${ }^{10)}$.

In clinical practice, we often experience a very high incidence of ALI/ARDS among septic patients. PMXDHP and sivelestat has been used to treat sepsis in patients with ALI/ARDS. A synergistic effect is expected due to the different targets and mechanisms of action of each treatment. In this study, we examined the efficacy of simultaneous treatment with PMX-DHP and sivelestat against endotoxemia using an in vivo model developed in our laboratory ${ }^{11-13}$. This model is unique in that it does not utilize anesthesia, and can therefore be used to measure levels of resting tension of intestinal smooth muscle and blood pressure, thereby affording greater accuracy than models that require sedation. Furthermore, the model has clinical relevance because it uses guinea pigs, which have a high sensitivity to endotoxins, like humans. We examined the effects of PMX-DHP and sivelestat on LPS-induced colonic movement paralysis, blood pressure and survival rate. We also studied the effects on high mobility group box-1 protein (HMGB-1) which is a mediator of lethal endotoxemia and sepsis whose signaling is influenced by Toll- like receptor (TLR) $-4{ }^{14,15}$. The goal of the study was to determine whether simultaneous administration of PMX-DHP and sivelestat counteracts the effects of endotoxemia and whether combined therapy is more effective than monotherapy.

\section{METHODS}

\section{Animal model}

Male Hartley guinea pigs (350 to $400 \mathrm{~g}$, Sankyo-labo Co. Tokyo, Japan) were used after approval of the Animal Experimental Ethical Review Committee of Nippon Medical School (No. 21-069). The animals were allowed free access to tap water and laboratory animal food and were housed in a temperature and humidity-controlled room with a 12-h light/dark cycle. They were acclimated to the experimental environmental conditions for at least
7 days before experiment.

\section{Surgical procedures}

Surgical procedures were carried out as described previously with a few modifications ${ }^{12}$. The guinea pigs were anesthetized with sodium pentobarbital ( $30 \mathrm{mg} / \mathrm{kg}$, i.p.), and the hair over the abdomen, anterior portion of the neck and between the scapulae was shaved. The skin was sterilized with povidone-iodine (Meiji, Tokyo, Japan). Surgery was performed with the animals on a warming pad maintained at $37^{\circ} \mathrm{C}$ under sterile conditions. First, a 3-Fr heparin-coated polyurethane catheter (CBAS-C30; Instech, Solomon, PA) was inserted into the left carotid artery to measure arterial pressure. Another catheter was then inserted into the jugular vein for drug administration. Both catheters were secured to the neck muscle, tunneled subcutaneously, and accessed between the scapulae. The exterior portions of the catheters were connected to a cannula swivel (Model TSC2-21; Tsumura, Tokyo, Japan). The arterial catheter was connected to a receiver (IMT-10RA; Star Medical, Tokyo, Japan) through a blood pressure transducer (Model DX-360; Nihonkohden, Tokyo, Japan). A force transducer $(3 \times 5$ $\mathrm{mm}, \mathrm{F}-041 \mathrm{~S}$; Star Medical) was then sutured to the taenia caecum to monitor intestinal movement. A cylindrical electric transmitter $(15 \times 35 \mathrm{~mm}$, IMT-10T; Star Medical) was connected to the transducer via a cable embedded beneath the dorsal skin and sutured in place. Signals from the transmitter were detected by a receiver (IMT10RA; Star Medical) placed directly beneath the cage. The transmitted data provided continuous records of tension changes in the intestinal longitudinal muscle and arterial pressure changes that were stored in a computer for later analysis.

\section{Extracorporeal circuits}

PMX in small modules (internal diameter, $5 \mathrm{~mm}$; length $13 \mathrm{~mm}$; capacity, approximately $1 \mathrm{ml}$; amount of immobilized polymyxin $\mathrm{B}$, approximately $3 \mathrm{mg}$ ) were provided by Toray Medical (Tokyo, Japan). To remove any residual free polymyxin B particles, the module was washed immediately before hemoperfusion with $20 \mathrm{ml}$ of heparinized saline (heparin, $25 \mathrm{U} / \mathrm{ml}$ ) and then with 20 $\mathrm{ml}$ of non-heparanized saline. The arterial catheter was connected to the cannula swivel on the day of surgery and was then connected an infusion pump (ZP-101H; Terumo; Tokyo) via a three-way stop-cock, and a PMX module was set up at the exit of the pump. The module was oriented vertically to allow upward flow of blood. 


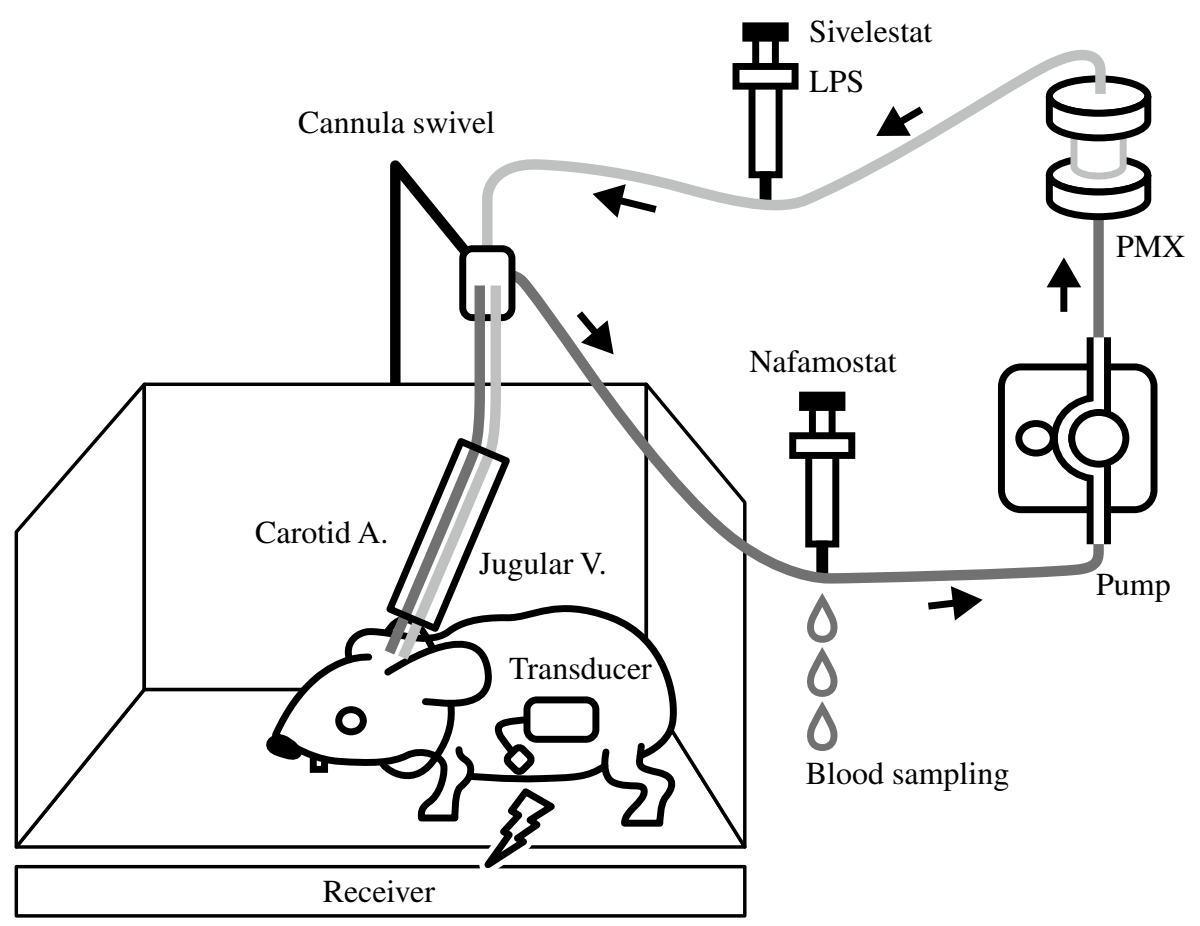

Fig. 1. Schematic of the experimental conditions.

LPS: lipopolysaccharide, PMX: polymyxin B immobilized fiber.

The venous catheter was connected to the exit flow of the module, completing the extracorporeal circuit.

\section{Measurement of colonic muscle tension (CMT) and mean arterial pressure (MAP)}

Animals were separated into four groups. All groups received LPS (10 mg/kg, i.v. bolus). The control group ( $\mathrm{n}=4)$ did not receive any further treatment. The PMX-DHP group $(\mathrm{n}=4)$ received PMX-DHP treatment $(30 \mathrm{ml} / \mathrm{h} \times 2$ h). The sivelestat group $(\mathrm{n}=4)$ received sivelestat $(30 \mathrm{mg} /$ $\mathrm{kg} / \mathrm{h}$ d.i.v. $\times 2 \mathrm{~h}$ ) treatment. The PMX-DHP + sivelestat group received sivelestat $(30 \mathrm{mg} / \mathrm{kg} / \mathrm{h}$ d.i.v. $\times 2 \mathrm{~h})$ and PMX-DHP $(30 \mathrm{ml} / \mathrm{h} \times 2 \mathrm{~h})$ treatment simultaneously.

In the PMX-DHP group, on the day following the operation, colonic movement and blood pressure had returned to normal, and direct hemoperfusion was carried out with the small PMX module (Fig. 1). LPS (10 mg/kg) was administered through the venous catheter after stable colonic movement and blood pressure were observed, 15 min after initiating treatment with PMX-DHP. PMXDHP treatment was continued for $2 \mathrm{~h}$ at $30 \mathrm{ml} / \mathrm{h}$ after administration of LPS. Nafanostat mesilate $(0.4 \mathrm{mg} / \mathrm{h})$ was used as an anticoagulant.

In the sivelestat group, LPS (10 mg/kg, i.v.) was administered 15 min after initiation of the sivelestat infu- sion $(45 \mathrm{ml} / \mathrm{h})$. Drip infusion of sivelestat was continued for $2 \mathrm{~h}$ after LPS administration due to the short blood half life of sivelestat (131.4 min). The concentration of sivelestat used was based on previous studies ${ }^{16)}$.

In the PMX-DHP + sivelestat group, LPS $(10 \mathrm{mg} / \mathrm{kg}$, i.v.) was administered $15 \mathrm{~min}$ after the simultaneous initiation of PMX-DHP (30 $\mathrm{ml} / \mathrm{h})$ and sivelestat infusion (45 $\mathrm{ml} / \mathrm{h})$.

Intestinal tension and blood pressure were measured from 30 min before administration of LPS to $6 \mathrm{~h}$ after, with readings taken every $30 \mathrm{~min}$.

\section{Measurement of serum HMGB-1}

Arterial blood $(0.5 \mathrm{ml})$ was obtained from each guinea pig before and 2, 4 and $6 \mathrm{~h}$ after the administration of LPS. Blood samples were immediately centrifuged at $2,000 \mathrm{~g}$ at $4^{\circ} \mathrm{C}$ for $10 \mathrm{~min}$. The isolated serum was stored at $-80^{\circ} \mathrm{C}$ until assay. HMGB-1 levels were measured using a HMGB-1 ELISA kit II (Shino-Test, Kanagawa, Japan).

\section{Mortality of guinea pigs injected with LPS}

To study survival rates, the guinea pigs were randomized into four groups and injected intravenously with LPS (10 mg/kg) $15 \mathrm{~min}$ after initiating PMX-DHP and/or 


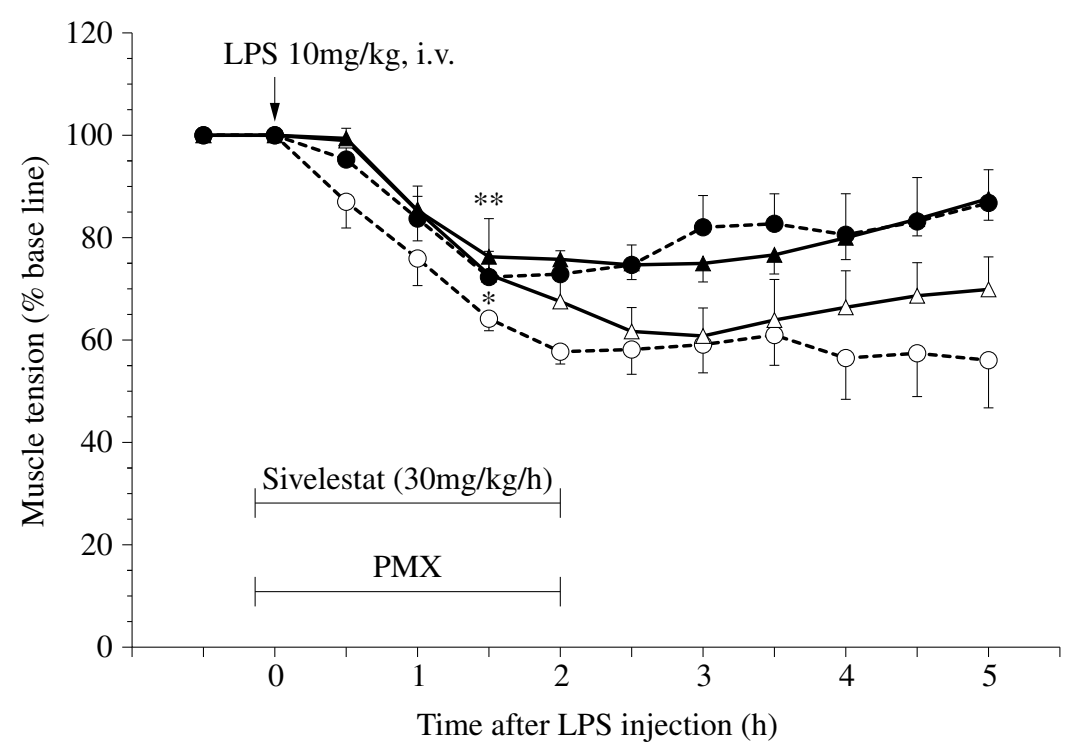

Fig. 2. Effects of PMX and/or sivelestat treatment on LPS-induced muscle relaxation. Guinea pigs were injected with LPS (10 mg/kg i.v.), at the time indicated by the arrow, 15 min after pretreatment with $\operatorname{PMX}(\boldsymbol{\Delta})$, sivelestat $(\triangle)$, $\operatorname{PMX}+$ sivelestat $(\boldsymbol{O})$ or vehicle $(\bigcirc)$. Treatment with $\operatorname{PMX}(\boldsymbol{\Delta})$ or PMX + sivelestat $(\bigcirc)$ significantly inhibited the decrease in colonic muscle tension observed after LPS injection $(* * \mathrm{p}<0.01$, *p $<0.05$ ), while sivelestat $(\triangle)$ had no significant effect. Mean values \pm SEM are shown ( $\mathrm{n}=4$ for each group).

$\bigcirc--\bigcirc$ LPS, $\triangle \Delta$ LPS+PMX, $\triangle \triangle$ LPS+Sivelestat, - - LPS+PMX+Sivelestat

sivelestat-infusion. Survival was assessed 6, 12, 18, 24, 30 and $36 \mathrm{~h}$ after treatment.

\section{Chemicals}

The following chemicals were used: heparin sodium (Wako Pure Chemical Industries, Osaka, Japan), lipopolysaccharide (LPS, E. coli serotype O111:B4; Sigma Chemical, St. Louis, MO), nafamostat mesilate (Futhan ${ }^{\mathrm{R}}$, Torii Pharmaceutical Co., Tokyo, Japan), pentobarbital sodium (Schering Plough, Kenilworth, NJ). Sivelestat sodium hydrate (Elaspol ${ }^{\mathrm{R}}$ ) was purchased from Ono Pharmaceuticals (Osaka, Japan). Chemicals were diluted in sterile saline.

\section{Statistical analysis}

All experimental results are shown as mean \pm SEM. Comparisons of two groups as a function of time were performed by repeated measures analysis of variance (ANOVA), followed by post hoc tests with Bonferroni correction. The data sampling times for the repeated measures ANOVA were $1,1.5$ and $2 \mathrm{~h}$ for the measure of CMT and MAP, and 2, 4 and $6 \mathrm{~h}$ for the measure of HMGB1 levels. The Kaplan-Meyer test was used for analyzing the effects of PMX-DHP or/and sivelestat on mor- tality in LPS-treated guinea pigs. P-values less than 0.05 were considered statistically significant.

\section{RESULTS}

\section{Effects of PMX and/or sivelestat on CMT and MAP fol- lowing LPS administration}

Following intravenous administration of LPS to the control group, CMT immediately began to decrease and reached a plateau after approximately $2 \mathrm{~h}$ at $58.0 \pm 2.6 \%$ of baseline levels (Fig. 2). In the PMX-DHP group, there was a significant inhibition $(\mathrm{p}=0.001)$ of the CMT depression $1,1.5$ and $2 \mathrm{~h}$ after LPS administration when compared with the control group. In the sivelestat group, there was an inhibition of CMT depression up to $2 \mathrm{~h}$ after LPS administration but it was not significant when compared with the control group. Also, in the siveletat group, CMT depression from 2.5 to $3.5 \mathrm{~h}$ after LPS administration was similar to the control group. After $3.5 \mathrm{~h}, \mathrm{CMT}$ started to increase. In the PMX-DHP + sivelestat group, there was a significant inhibition $(\mathrm{p}=0.001)$ of the CMT depression after LPS administration. The CMT values of the control and PMX-DHP + sivelestat groups were significantly different $(\mathrm{p}=0.01)$. There was no significant 


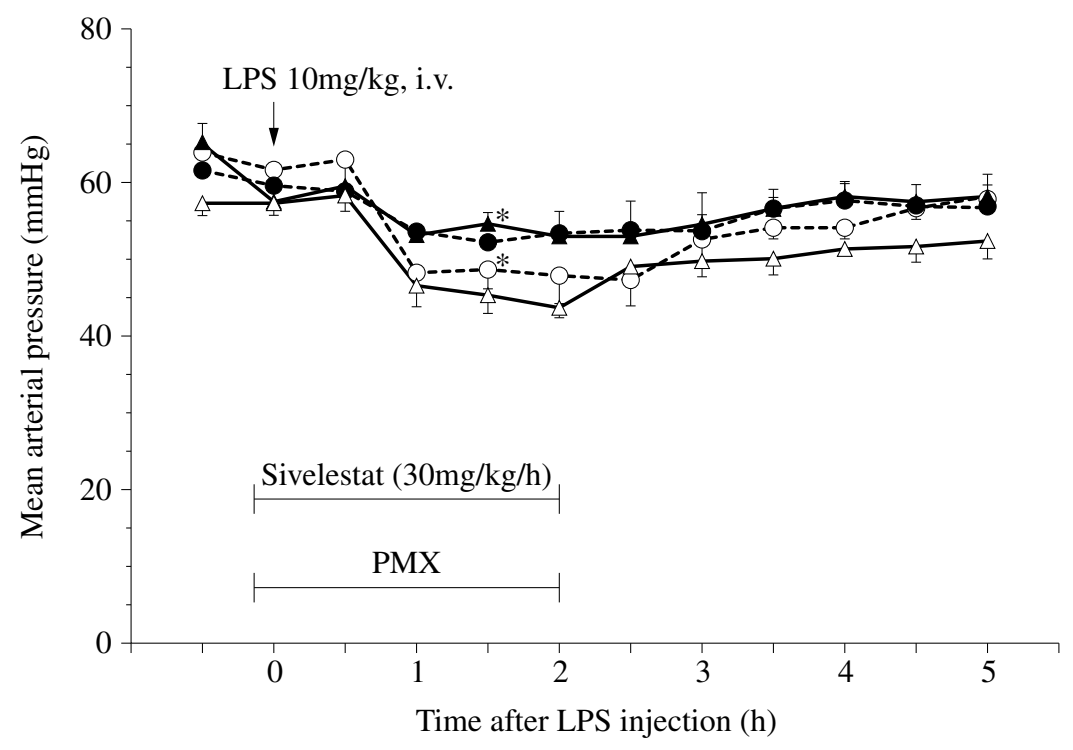

Fig. 3. Effects of PMX and/or sivelestat on LPS-induced hypotension. Guinea pigs were injected with LPS (10 mg/kg i.v.), at the time indicated by the arrow, $15 \mathrm{~min}$ after pretreatment with $\operatorname{PMX}(\boldsymbol{\Delta})$, sivelestat $(\triangle)$, PMX + sivelestat $(\boldsymbol{O})$ or vehicle $(\bigcirc)$. Treatment with $\mathrm{PMX}(\boldsymbol{\Delta})$ or PMX + sivelestat $(\boldsymbol{O})$ significantly inhibited the decrease in mean arterial pressure observed after LPS injection $(* p<0.05)$, while sivelestat $(\triangle)$ had no significant effect. Mean values \pm SEM are shown ( $\mathrm{n}=4$ for each group).

$\bigcirc--\bigcirc$ LPS,$\triangle \Delta$ LPS+PMX, $\triangle \triangle$ LPS+Sivelestat, - - LPS+PMX+Sivelestat

difference in CMT values between the PMX-DHP group and PMX-DHP + sivelestat group, indicating that there is no synergistic effect of the two treatments on the recovery of CMT.

In the control group, MAP was $61.7 \pm 2.1 \mathrm{mmHg}$ before LPS administration and dropped to $48.4 \pm 2.7 \mathrm{mmHg} 1 \mathrm{~h}$ after LPS administration (Fig. 3). In the PMX-DHP group, MAP levels were $52.9 \pm 1.1 \mathrm{mmHg} 1 \mathrm{~h}$ after LPS administration, indicating that PMX-DHP significantly improved MAP depression induced by LPS administration. There was a significant difference in MAP values between the control and PMX-DHP groups $(\mathrm{p}=0.01)$. There was no significant difference in MAP values between the sivelestat and control groups. In the PMX-DHP + sivelestat group, the treatment significantly improved MAP depression induced by LPS administration. There was a significant difference in MAP values between the control group and PMX-DHP + sivelestat group $(\mathrm{p}=0.04)$. However, there was no significant difference in the effect on MAP values between the PMXDHP and PMX-DHP + sivelestat groups.

\section{Effects of PMX and/or sivelestat on LPS-induced in- creases in serum HMGB-1 levels}

In the control group, serum levels of HMGB-1 increased with time after LPS administration (Fig. 4). How- ever, sivelestat inhibited the rise in serum levels of HMGB- 1 at $2 \mathrm{~h}$ after LPS administration. At 2, 4 and $6 \mathrm{~h}$, increases in serum HMGB-1 levels were significantly inhibited by $60.0,49.0$ and $68.6 \%$, respectively, as compared to the control group ( $\mathrm{p}=0.02)$. There was no significant difference between the PMX-DHP, PMX-DHP + sivelestat and control groups at all time points. There was no significant difference between the PMX-DHP + sivelestat and sivelestat groups.

Effects of PMX and/or sivelestat on LPS-induced decreases on survival rates

The survival rate was significantly higher in the PMXDHP group than in the control group (Fig. 5). The PMXDHP + sivelestat and sivelestat group survival rates were, higher than the control group, but there was no statistically significant difference. There was no significant difference between the survival rates for the PMX-DHP + sivelestat and PMX-DHP groups.

\section{DISCUSSION}

Treatment of endotoxin shock has been approached in two ways. The first approach is to remove circulating endotoxins. One method for endotoxin removal is perfusion 


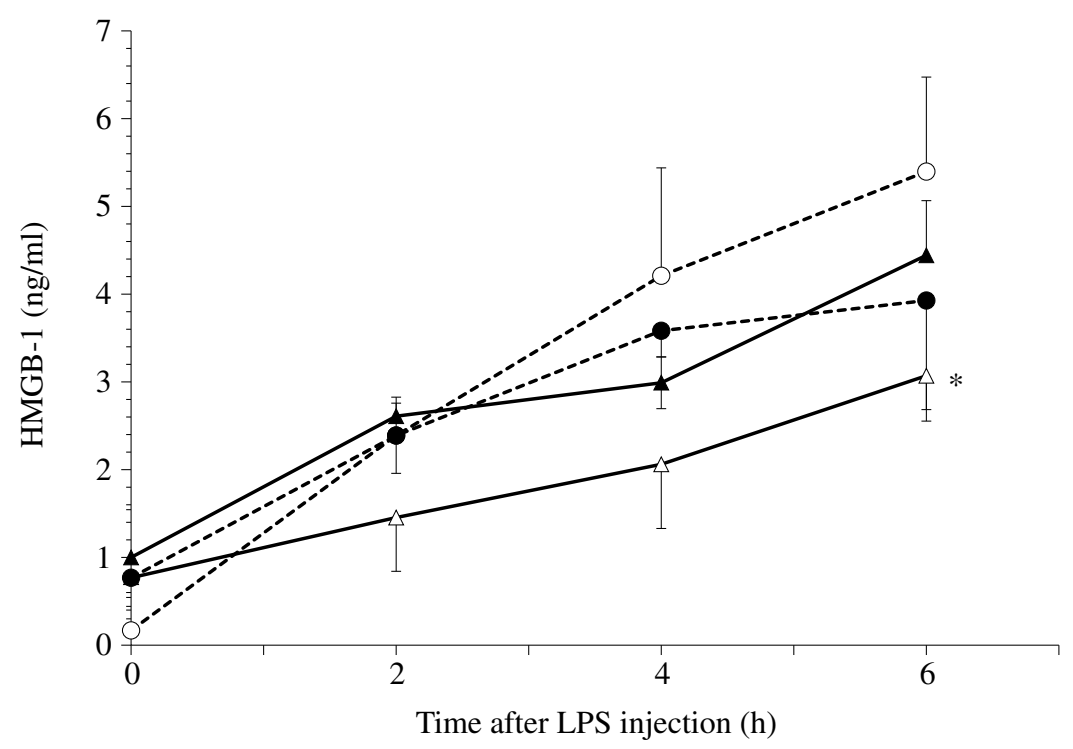

Fig. 4. Effect of PMX and/or sivelestat on HMGB-1 levels induced by LPS. Guinea pigs were injected with LPS $(10 \mathrm{mg} / \mathrm{kg}$ i.v. $)$ at time point 0 . Treatment with sivelestat $(\triangle)$ significantly inhibited the increase in HMGB-1 levels induced by LPS $(* \mathrm{p}<0.05)$. Mean values \pm SEM are shown ( $n=4$ for each group).

$\bigcirc--\bigcirc$ LPS,$\triangle \Delta$ LPS+PMX, $\triangle \triangle$ LPS+Sivelestat, - - LPS+PMX+Sivelestat

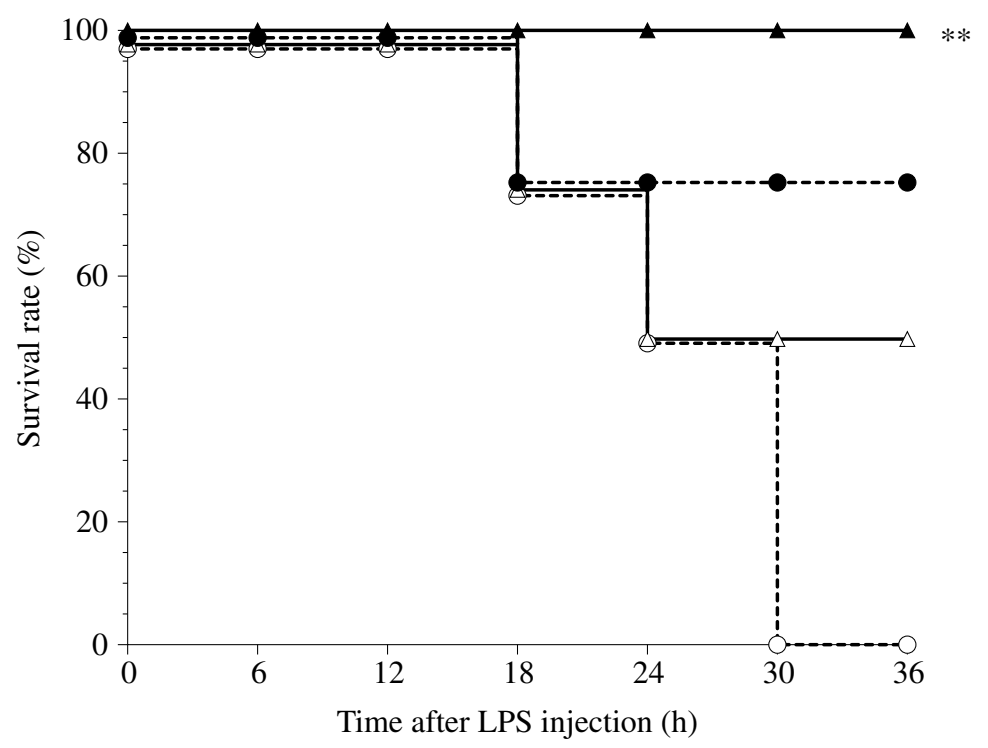

Fig. 5. Effects of PMX and/or sivelestat on survival rate of guinea pigs injected with LPS. Mortality was examined 6, 12, 18, 24, 30 and $36 \mathrm{~h}$ after LPS injection. Treatment with PMX ( $\boldsymbol{\Delta}$ ) significantly increased survival rate in LPS-treated animals as analyzed using the Kaplan-Meyer test. $\mathrm{n}=4$ for each group. ${ }^{*} \mathrm{p}<0.01$, compared with control group.

$\bigcirc--\bigcirc$ LPS,$\triangle \Delta$ LPS+PMX, $\triangle \triangle$ LPS+Sivelestat, - - LPS+PMX+Sivelestat 
through medical devices consisting of polymyxin B immmobilized fiber (PMX) columns. The second approach is to target the many pro-inflammatory mediators induced by endotoxin exposure. In the present study, we investigated the combined effects of these two approaches using PMX-DHP and sivelestat treatment in vivo guinea pig model of endotoxaemia. We found that PMX-DHP effectively treated the symptoms of severe endotoxaemia induced by high dose LPS administration. However, simultaneous administration of sivelestat did not result in a synergistic effect.

It has been shown that LPS-induced CMT and MAPdepression are LPS-dose dependent. Administration of LPS at $10 \mathrm{mg} / \mathrm{kg}$, i.v. showed the maximum reaction and resulted in death of all subjects in a previous study ${ }^{11}$. For such severe endotoxaemia, PMX treatment was clearly effective and significantly improved survival rates. PMX treatment removes LPS and LPS-induced endocannabinoids ${ }^{5,12}$. Endocannabinoids, particularly 2 -arachidonylglycerol (2-AG), are attracting attention as early initial mediators of sepsis ${ }^{17,18)}$. PMX treatment is effective because it is etiotropic. In contrast, sivelestat inhibited the decrease of CMT immediately after LPS administration, but was ineffective against the high dose of LPS $2 \mathrm{~h}$ after administration when the systemic inflammatory response had expanded ${ }^{19}$.

In the present study, we also measured HMGB-1, a mediator of inflammation, during LPS-induced endotoxaemia using an HMGB-1 ELISA Kit II capable of detecting trace levels of HMGB-1 ${ }^{20)}$. HMGB1 levels increased immediately after LPS administration and continued to increase with time. Sivelestat significantly suppressed LPS-induced increases in HMGB1 levels. These results indicate that HMGB1 production increases early in the LPS-mediated activation of neutrophils, and that sivelestat can inhibit this process. While PMX-DHP reduced the levels of HMGB1, there was no significant difference compared to the control group. HMGB1 levels were not suppressed in the PMX-DHP + sivelestat group but were suppressed in the sivelestat group. This result indicates that PMX-DHP may counteract the action of sivelestat. However, there was no significant difference between the two groups. Interestingly, PMX-DHP treatment significantly improved survival rates, indicating that the increases in HMGB1 levels observed up to $6 \mathrm{~h}$ after LPS administration may not be correlated with survival rates. In the later phase, it has been reported that higher HMGB1 levels lead to higher mortality in vivo ${ }^{21)}$. Therefore, it is necessary to determine the levels of HMGB1 in the later phase. The improved survival rates with PMXDHP treatment were decreased in the presence of sivelestat. Although there was no significant difference in survival rates between the groups treated with PMX-DHP with sivelestat or PMX-DHP alone, sivelestat administration might reverse the effects of PMX-DHP. Additional studies are needed to better understand the interactions of PMX-DHP and sivelestat.

We have previously shown that the dose of sivelestat $(30 \mathrm{mg} / \mathrm{kg} / \mathrm{h})$ used in this in vivo study improved the symptoms of low dose LPS administration $(0.3 \mathrm{mg} /$ $\mathrm{kg})^{13)}$. In the previous study, it was shown that early infusion of sivelestat effectively improved outcomes. In the present study, using a high LPS dose $(10 \mathrm{mg} / \mathrm{kg})$, sivelestat at $30 \mathrm{mg} / \mathrm{kg} / \mathrm{h}$ (sufficiently high dose) showed only limited effects. For acute lung injuries in humans, the therapeutic dose of sivelestat is $0.2 \mathrm{mg} / \mathrm{kg} / \mathrm{h}$. In the STRIVE clinical study, however, sivelestat was not effective ${ }^{10)}$. This finding was different from tests carried out in Japanese patients with less severe acute lung injury, where the treatment was effective ${ }^{8}$. In contrast, for PMX treatment, significant positive clinical effects were observed during the EUPHAS study carried out in Italy ${ }^{22}$. Clinical studies of PMX are currently ongoing in several other countries. As a result of these clinical studies, PMX will likely be used for the treatment of sepsis in countries other than Japan.

In summary, we studied the effect of a combination therapy using PMX and sivelestat treatment with a guinea pig model of endotoxaemia. PMX treatment alone improved survival rates, inhibited intestinal damage and counteracted depression of blood pressure. However, no synergistic effect was observed with simultaneous PMX and sivelestat treatment. Although sivelestat suppressed LPS-induced increases in HMGB1 levels, it did not result in improvement of the symptoms.

\section{REFERENCES}

1) Cohen J: The immunopathogenesis of sepsis. Nature. 2002; 420: 885-91.

2) Moscolo N, Izzo AA, Ligresti A, et al: The endocannabinoid system and the molecular basis of paralytic ileus in mice. FASEB J. 2002; 16: 1973-5.

3) Varga K, Wagner JA, Bridgen DT, et al: Platelet- and macrophage- derived endogenous cannabinoids are involved in endotoxin- induced hypotension. FASEB J. 1998; 12: 1035-44.

4) Ninomiya N, Nemoto K, Kaji M, et al: Regulation of the endocannabinoid system in endotoxicosis of conscious guinea 
pigs. J Jpn Assoc Acute Med. 2005; 16: 218-26.

5) Shiga N, Nemoto K, Shimada Y, et al: Elimination of 2-arachidonoylglycerol action by direct hemoperfusion through fibers immobilizing polymyxin B: An experimental study in conscious guinea pigs. Ther Apher Dial. 2006; 10: 504-9.

6) Kase Y, Obata T, Nishida H, et al: Cardiovascular effects of removing endogenous cannabinoids using direct hemoperfusion therapy with polymyxin-B immobilized fiber in septic patients. Jpn J Crit Care Endotoxemia. 2003; 7: 30-5.

7) Wang Y, Liu Y, Ito Y, et al: Simultaneous measurement of anandamide and 2-arachidonoylglycerol by polymyxin B-selective adsorption and subsequent high-performance liquid chromatography analysis: increase in endogenous cannabinoids in the sera of patients with endotoxic shock. Anal Biochem. 2001; 294: 73-82.

8) Tamakuma S, Ogawa M, Aikawa N, et al: Relationship between neutrophil elastase and acute lung injury in humans. Pulm Pharmacol Ther. 2004; 17: 271-9.

9) Sakamaki F, Ishizaka A, Urano T, et al: Effect of a specific neutrophil elastase inhibitor, ONO-5046, on endotoxin-induced acute lung injury. Am J Respir Crit Care Med. 1996; 153: 391-7.

10) Zeiher BG, Artigas A, Vincent JL, et al: Neutrophil elastase inhibition in acute lung injury: results of the STRIVE study. Crit Care Med. 2004; 32: 1695-702.

11) Ninomiya $N$, Nemoto $K$, Okamura $T$, et al: A novel experimental method for the study of intestinal paralysis due to endotoxicosis. J Jap Assoc Acute Med. 2003; 14: 241-50.

12) Nakanowatari $Y$, Nemoto $K$, Hara $S$, et al: Effects of direct haemoperfusion through fibres immobilizing polymyxin $\mathrm{B}$ and nafamostat mesilate on endotoxaemia in conscious guin- ea- pigs. Clin Exp Pharmacol Physiol. 2008; 35: 17-22.

13) Hara $S$, Nemoto K, Ninomiya N, et al: Continuous infusion of sivelestat sodium hydrate prevents lipopolysaccharide- induced intestinal paralysis and hypotension in conscious guinea- pigs. Clin Exp Pharmacol Physiol. 2008; 35: 841- 5.

14) Tsung A, Sahai R, Tanaka H, et al: The nuclear factor HMGB1 mediates hepatic injury after murine liver ischemia- reperfusion. J Exp Med. 2005; 201: 1135-43.

15) Park JS, Robertson FG, He Q, et al: High mobility group box 1 protein interacts with multiple Toll- like receptors. Am J Physiol Cell Physiol. 2006; 290: 917-24.

16) Kaji M, Nemoto K, Kubota M, et al: Preventive effects of sivelestat sodium hydrate on lipopolysaccharide-induced intestinal paralysis in conscious guinea pigs. J Jap Assoc Acute Med. 2006; 17: 845-53.

17) Harada N, Nemoto K, Okamura T, et al: Effects of cannabinoids on colonic muscle contractility and tension in guinea pigs. J Nippon Med Sch. 2005; 72: 43-51.

18) Inagaki $E$, Nemoto $K$, Ninomiya $N$, et al: Rimonabant, a specific antagonist of the cannabinoid CB1-receptor, prevents lipopolysaccharide-induced endotoxemia in awake guinea pigs. J Jap Assoc Acute Med. 2010; 21: 118-25.

19) Nakano M, Kodama M. Endotoxemia. In: Endotoxin. Kodansya Ltd., Tokyo, 1995, p189-90.

20) Yamada $S$, Yakabe $K$, Ishii J, et al: New high mobility group box 1 assay system. Clinica Chemica Acta. 2006; 372: 173-8.

21) Wang H, Bloom O, Zhang M, et al: HMG-1 as a late mediator of endotoxin lethality in mice. Science. 1999; 285: 248-51.

22) Cruz DN, Antonelli M, Fumagalli R, et al: Early use of polymyxin $\mathrm{B}$ hemoperfusion in abdominal septic shock. JAMA. 2009; 301: 2445-52. 
原著論文

\section{エンドトキシン血症モルモットにおける PMX-DHP, sivelestat同時適用の効果}

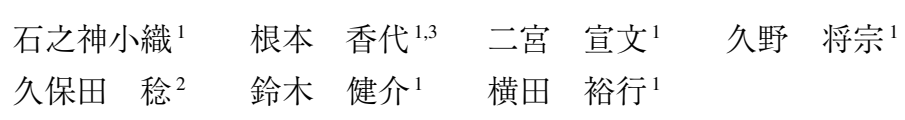

要旨 エンドトキシン血症モルモットモデルにおいて, PMX-DHP 施行および sivelestat 投与が各々有効であるこ とは既に報告した。本研究において我々は両者の同時適用によって, より高い有効性が得られるのかを検討し た。効果の判定には, lipopolysaccharide（LPS 10mg.kg, i.v.）誘発腸管麻痺および血圧低下に対する効果, 血中 HMGB1 濃度, 救命率に対する効果を検討した。テレメトリー法により圧トランスデューサーを介した結腸縦走 筋張力を経時的に測定した。また, 頸動脈カテーテルを介して動脈圧をモニターし, 頸静脈カテーテルから薬 物を静脈内投与した。モルモットを4群に分け, 対照群にはLPSを投与し, PMX-DHP施行群にはLPS投与およ びPMX-DHP2 時間施行を行い, sivelestat投与群にはLPS投与およびsivelestat 2 時間持続投与を行い, 同時適用群 にはLPS 投与および sivelestat 2 時間持続投与下でPMX-DHP 2 時間施行を行った。対照群では, LPS投与後時間 経過に従った結腸縦走筋の弛緩反応と血圧低下および血中HMGB1増加が認められ, 全例30時間以内に死亡した。 PMX-DHP施行群では, LPSによる腸管弛緩および血圧低下は有意に抑制され, 生存率は増加したが, 血中 HMGB1は抑制されなかった。Sivelestat投与群では, LPSによる腸管弛緩および血圧低下は抑制されなかったが, 血中HMGB1は抑制された。同時にPMX-DHP施行と sivelestat 持続投与を行った場合, 各々の適用時よりも効果 が増強されることはなかった。以上の結果から, 高濃度LPS投与により惹起したモルモットの重症エンドトキシ ン血症に対してPMX-DHPは有効であるが，同時に sivelestat を投与しても効果は増強されなかった。

(日救急医会誌. 2012; 23: 12-20)

キーワード：HMGB-1, 腸管麻疩, リポ多糖, 敗血症

原稿受理日：2011年4月 15 日（11-036）

${ }^{1}$ 日本医科大学救急医学講座 ${ }^{2}$ 日本医科大学多摩永山病院中央検查室 ${ }^{3}$ 新宿鍼尒柔整専門学校機能系研究室 著者連絡先：干 206-8512 東京都多摩市永山 1-7-1 日本医科大学多摩永山病院救命救急センター 